\title{
Drying characteristics of Turkish ravioli, mantı
}

\section{Mantıların kurutma karakteristiği}

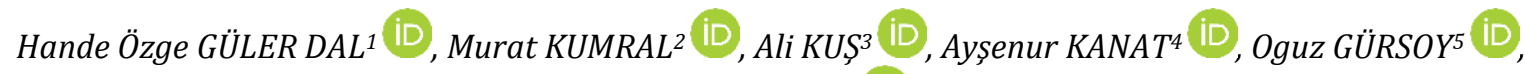 \\ Yusuf YILMAZ ${ }^{*}$ iD
}

1,2,3,4,5,6 Department of Food Eng., Faculty of Engineering and Architecture, Burdur Mehmet Akif Ersoy University, Burdur, Turkey. handeguler@mehmetakif.edu.tr, mrtkmr1324@gmail.com, ali_kus35@gmail.com, aysenur.kanat1@gmail.com, ogursoy@yahoo.com, yilmaz4yusuf@yahoo.com

\section{Abstract}

Mantr is a type of ravioli with a unique taste, which has been appreciated by many people in Turkey for years. In this study, two common types of mantı samples (traditional Kayseri mantı produced by wrapping dough sheets into small bags and triangular manti) were dried to make them microbiologically safe by lowering their water activities to a desired level of less than 0.6. Drying process was carried out in a conventional dryer at 60,70 and $80^{\circ} \mathrm{C}$ and the drying kinetics of mant samples was determined by the Page, Henderson and Pabis, Modified Page, Logarithmic and Newton models. The best-fit model for the drying characteristics of triangular mantı was the Newton model at 60 and $70^{\circ} \mathrm{C}$ while the Page and Modified Page models were the best at $80^{\circ} \mathrm{C}$. Moreover, Page/Modified Page, Newton and Page/Modified Page models were the best-fit models for traditional Kayseri mantı at $60{ }^{\circ} \mathrm{C}$ $70{ }^{\circ} \mathrm{C}$ and $80{ }^{\circ} \mathrm{C}$, respectively. Faster drying rates were obtained for triangular mantı, and the desired water activity value for this mantı was reached at drying temperatures of $70^{\circ} \mathrm{C}$ and $80^{\circ} \mathrm{C}$, and only at $80^{\circ} \mathrm{C}$ for the traditional Kayseri mant. Drying rates increased by increasing temperature levels.

Anahtar kelimeler: Turkish ravioli, Drying kinetics, Water activity, Modelling, Drying rate.

\section{Introduction}

Bakery products are an important group of foods made by the addition of various components to dough and widely consumed in many countries. Mantı is one of the traditional Turkish dishes included in this group containing meat and dough, which are generally preferred constituents by a wide range of consumers [1]. Mantı is sold as packed, unpacked, chilled, frozen or baked, and the main materials of this traditional product are wheat flour, water and eggs. Some types of mantı may contain other materials such as mashed potatoes, cheese, minced meat and spices. Generally, mantı is prepared by filling these various materials into the rectangular or other kinds of shaped dough parts. Products similar to mantı include ravioli, tortellini and pelmeni, which are consumed in Italy and many countries around the world [2],[3].

Chemical, enzymatic and microbial deterioration in foods during storage depends on their water activity levels and the microbial growth is almost completely restricted at levels below 0.6 (Roos 2001). The moisture content of ravioli and tortellini, products similar to mantı, ranges from 26 to $34 \%$ while their water activity values varies from 0.92 to 0.95 [4]. Therefore, one of the most effective factors on the deterioration
Öz

Mantı, Türkiye'de yıllardır birçok insan tarafindan tüketilen, özgün tada sahip bir hamur ișidir. Bu çalıșmada, iki yaygın tipte mantı örneği (hamur tabakalarının küçük torbalar halinde sarılmasıyla üretilen geleneksel Kayseri mantısı ve üçgen mantı) mikrobiyolojik olarak güvenli olmalarını sağlamak amacıyla su aktivitesi değerlerinin 0.6'nın altına düşürülmesi suretiyle kurutulmuştur. Kurutma işlemi konvektif bir kurutucuda 60,70 ve $80{ }^{\circ} \mathrm{C}^{\prime} \mathrm{de}$ gerçekleștirilmiș ve örneklerin kurutma kinetiği parametreleri Page, Henderson ve Pabis, Modifiye Page, Logaritmik ve Newton modelleri kullanılarak belirlenmiştir. Ücgen mantının kuruma özelliklerine en uygun modeller 60 ve $70^{\circ} \mathrm{C}$ için Newton modeli iken, $80^{\circ} \mathrm{C}$ için en uygun modeller Page ve Modifiye Page modelleridir. Ayrıca, $60{ }^{\circ} \mathrm{C}, 70{ }^{\circ} \mathrm{C}$ ve $80^{\circ} \mathrm{C}^{\prime}$ de geleneksel Kayseri mantı için en uygun modeller sirasiyla Page/Modifiye Page, Newton ve Page/Modifiye Page olarak saptanmıştır. Üçgen mantı için daha yüksek kuruma hızları saptanırken, istenen su aktivite değeri üçgen mantı için $70^{\circ} \mathrm{C}$ ve $80^{\circ} \mathrm{C}$, geleneksel Kayseri mantısı için ise yalnızca $80^{\circ} \mathrm{C}$ kurutma sıcaklığında elde edilmistir. Kuruma hızları sıcaklık ile artıs göstermiştir.

Anahtar kelimeler: Mantı, Kurutma kinetiği, Su aktivitesi, Modelleme, Kuruma hızı.

\section{${ }^{*}$ Corresponding author/Yazışılan Yazar}

of mantı is its moisture content and nutritional value which are subjected to mostly lipid oxidation or microbial growth [5]. Although high-moisture foods such fresh pasta, pizza dough and mantı are dried at high temperature, pathogens like Salmonella spp. and S.auerus can survive in the final product. As drying continues, their water activity values fall below 0.8 , which results in the inhibition of bacterial growth over time [6]. Technologically, drying is the process of making a food product more stable by lowering its water content under constant and safe conditions. The most common applications in the drying of agricultural products are tunnel and cabinet-type dryers included in hot air dryers. Because of their simplicity and low costs, these types of dryers are commonly used [7],[8].

Several studies on the drying processes of mantı like bakery products are available in the literature as pasta [9]-[12], noodles [13]-[15]. Also, Dağlığlu [2] investigated the quality attributes of mantı samples subjected to microwave drying.

During drying processes, determining the drying characteristics of foods is highly critical to obtain final products with superior quality, which directly depends on drying conditions [16]. To the best of our knowledge, the drying characteristics of mantı samples with different shapes have not been studied yet. Therefore, this study was aimed to determine 
the drying characteristics of traditional Kayseri and triangular mantı samples at three different temperatures and to find out the best fit mathematical model for the experimental data.

\section{Materials and methods}

Frozen traditional Kayseri mantı and triangular mantı samples were obtained from a national market in Turkey. The average thickness values of triangular and traditional Kayseri mant samples were $10 \pm 0.3$ and $12 \pm 0.2 \mathrm{~mm}$ respectively. Samples were thawed in a refrigerator until their central temperature reached $4 \pm 1{ }^{\circ} \mathrm{C}$, which was monitored regularly by a thermometer with a stainless steel probe (Testo 720, Testo Inc., Lenzkirch, Germany). Then, samples were kept at room temperature for an hour to allow the moisture balance between outer dough sheet part and inner minced meat part of mantı samples.

Drying operations were performed by natural convection in a preheated oven (FN 500, Nüve, Ankara, Turkey) at 60, 70 and $80^{\circ} \mathrm{C}$ with 3 replications for each temperature. During drying, weight loss was monitored gravimetrically by a digital balance (Weightlab WL-3002L, Germany) and results were recorded. Drying procedure was carried out until the water activity value fell below 0.6. The initial moisture content of the mantı samples were determined as about $0.350 \mathrm{~g}$ water. $\mathrm{g}^{-1}$ dry matter and the final value was about $0.059 \mathrm{~g}$ water. $\mathrm{g}^{-1}$ dry matter for Kayseri mantı and 0,029 g water. $\mathrm{g}^{-1}$ dry matter for triangular mant samples. At the end of drying, mantı samples were carefully wrapped in aluminum foil, placed in plastic containers, and kept under refrigerated conditions for $48 \mathrm{~h}\left(+4 \pm 1^{\circ} \mathrm{C}\right)$. Then, water activities of the samples were determined using the water activity device (Testo 645, Testo Inc., Lenzkirch, Germany). Total dry matter contents of mantı samples were determined by drying at $105 \pm 1^{\circ} \mathrm{C}$ for $8 \mathrm{~h}$. Moisture contents of mantı samples were calculated based on the Equation 1.

$$
M_{t}=\frac{m-D M}{D M}
$$

where $M_{t}$ represents the moisture content value at any time (g water. $\mathrm{g}^{-1}$ dry matter), $m$ is the sample weight (g) and $D M$ is the dry matter content of mantı (g).

Moisture ratio values were calculated according to Equation 2:

$$
M R=\frac{M_{t}-M_{e}}{M_{0}-M_{e}}
$$

where $M R$ and $M_{t}$ are the moisture ratio and the moisture content at any t time (g water. $\mathrm{g}^{-1}$ dry matter); $M_{e}$ and $M_{0}$ are the equilibrium moisture content and initial moisture content values (g water. $\mathrm{g}^{-1}$ dry matter), respectively. During the food drying processes, $M_{e}$ may not be used in calculations because it is very small compared to $M_{t}$ and $M_{0}$ that does not influence the results [17]. The rate of drying is found by taking the derivate of drying time curves versus moisture content which is represented by the Equation 3.

$$
\text { Drying Rate }=\frac{\mathrm{M}_{\mathrm{t}+\mathrm{dt}}-\mathrm{M}_{\mathrm{t}}}{\mathrm{dt}}
$$

where $\mathrm{M}_{\mathrm{t}+\mathrm{dt}}$ represents the moisture content at $t+d t$ time ( $\mathrm{g}$ water $\mathrm{g}^{-1}$ dry matter) and $t$ is the drying time (h).

Drying rates and $M R$ values of mantı samples were determined from experimental drying data. To determine the mathematical drying kinetics of the samples, semi-empirical models were used (Table 1).
Table 1. Thin layer drying models used for modelling experimental data.

\begin{tabular}{ccc}
\hline Models & Equation & Reference \\
\hline Henderson and Pabis & $M R=a e^{(-k t)}$ & {$[18]$} \\
Newton & $M R=e^{(-k t)}$ & {$[19]$} \\
Page & $M R=e^{\left(-k t^{n}\right)}$ & {$[20]$} \\
Modified Page & $M R=e^{(-k t)^{n}}$ & {$[21]$} \\
Logarithmic & $M R=a e^{(-k t)}+c$ & {$[22]$} \\
\hline
\end{tabular}

For the statistical evaluation the coefficient of determination $\left(\mathrm{R}^{2}\right)$, root mean square error $(R M S E)$ and chi-square $\left(\chi^{2}\right)$ parameters were used to obtain the correspondence between the experimental and theoretical $M R$ values of kinetic models.

$$
\begin{aligned}
R M S E & =\left[\frac{1}{\mathrm{~N}} \sum_{\mathrm{i}=1}^{\mathrm{N}}\left(\mathrm{MR}_{\mathrm{prd}, \mathrm{i}}-\mathrm{MR}_{\text {exp }, \mathrm{i}}\right)^{2}\right]^{0.5} \\
\chi^{2} & =\frac{\sum_{\mathrm{i}=1}^{\mathrm{n}}\left(\mathrm{MR}_{\mathrm{exp}, \mathrm{i}}-\mathrm{MR}_{\mathrm{prd}, \mathrm{i}}\right)^{2}}{\mathrm{~N}-\mathrm{n}}
\end{aligned}
$$

where $\mathrm{MR}_{\text {prd }}$ is the estimated moisture content, $\mathrm{MR}_{\text {exp }}$ is the experimental moisture content, $\mathrm{n}$ and $\mathrm{N}$ are the number of coefficients in the tested model and number of the experimental data, respectively. RMSE values show the deviation between the estimated values obtained from the tested model and the experimental values. A decrease in chisquare $\left(\chi^{2}\right)$ value represents an increase in conformance. The lower values of $\chi^{2}$ and $R M S E$ with higher values of $\mathrm{R}^{2}$ are desirable.

\section{Results and discussion}

Figures 1 and 2 show the graphical representation of drying rates versus moisture content (MC) values at three different temperatures for triangular and traditional Kayseri mantı samples, respectively.

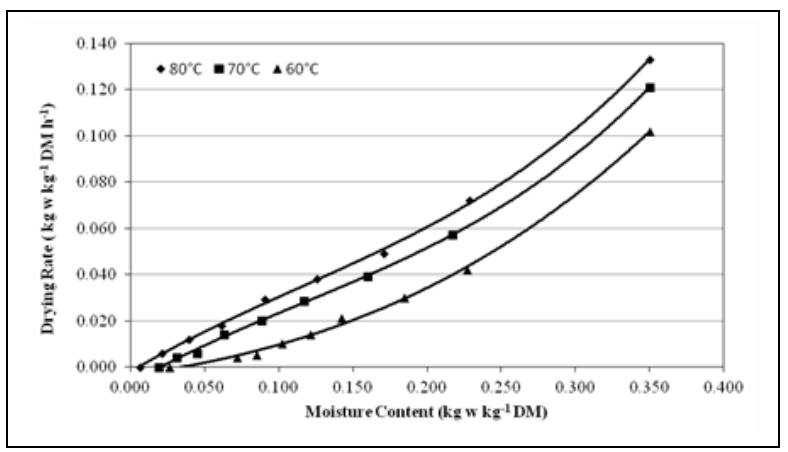

Figure 1. Drying rates and moisture contents of triangular mantı samples at three different temperatures.

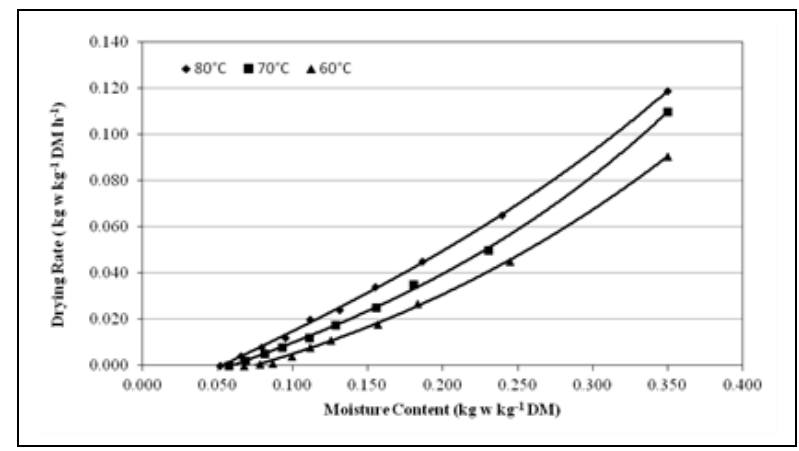

Figure 2. Drying rates and moisture contents of traditional Kayseri mantı samples at three different temperatures. 
Drying behavior of both mantı types (Figures 1 and 2) indicated that their drying rate increased with increasing drying temperature, as expected. Due to the rapid movement of moisture, a falling rate period occurred while no constant rate period was detected during drying. Results were similar to other food products reported in the literature such as cassava crackers [23], rice noodles [24] and crisp bread [25]. The highest drying rates were calculated at $80{ }^{\circ} \mathrm{C}$.

In terms of water activity $\left(\mathrm{a}_{\mathrm{w}}\right)$ values, triangular mantı samples were unable to reach the desired aw value of $\leq 0.6$ at $60^{\circ} \mathrm{C}$ at the end of $8 \mathrm{~h}\left(\mathrm{a}_{\mathrm{w}}=0.724\right)$. At $70^{\circ} \mathrm{C}$ the water activity of these samples was 0.598 after $7 \mathrm{~h}$ of drying while it was 0.690 and 0.346 in samples dried at $80{ }^{\circ} \mathrm{C}$ for $5 \mathrm{~h}$ and $6 \mathrm{~h}$, respectively. Besides, the water activity value of traditional Kayseri mant samples was 0.605 after $8 \mathrm{~h}$ at $80^{\circ} \mathrm{C}$. Drying temperatures of 60 and $70{ }^{\circ} \mathrm{C}$ were barely enough to achieve a desirable water activity value within $8 \mathrm{~h}$ of drying process $(0.753$ and 0.781 , respectively).

Results of five different thin layer models are given in Tables 2 and 3 for triangular and traditional Kayseri mantı samples, respectively. The coefficient of determination values of kinetic models were between 0.985 and 0.999 . Also, RMSE and $\chi^{2}$ values for both mantı samples ranged from $0.053 \times 10^{-2}$ to $16.687 \times 10^{-2}$ and from $0.003 \times 10^{-3}$ to $30.616 \times 10^{-3}$, respectively.
For triangular mantıs dried at $60^{\circ} \mathrm{C}$, the Newton model had the smallest $R M S E$ and $\chi^{2}$ values, which indicated that it explained the drying curves the best. At $70{ }^{\circ} \mathrm{C}$, the Newton, Page and Modified Page models explained the drying characteristics of this type of mantı samples similarly, but the Newton model had lower RMSE and $\chi^{2}$ values than the others. Also, Page and Modified Page models were the most convenient for drying at $80{ }^{\circ} \mathrm{C}$ with the highest $\mathrm{R}^{2}$ and lowest $R M S E$ and $\chi^{2}$ values (Table 2).

According to the Table 3, Modified Page and Page models were the best-fit models for the drying characteristics of the traditional Kayseri mantıs, having the highest $\mathrm{R}^{2}$ value and the lowest $R M S E$ and $\chi^{2}$ values at $60{ }^{\circ} \mathrm{C}$. For drying at $70{ }^{\circ} \mathrm{C}$, the lowest $R M S E$ and $\chi^{2}$ values were obtained by the Newton model, which explained the drying curves better than other models (Table 3). At the drying temperature of $80{ }^{\circ} \mathrm{C}$, Page, Modified Page and Logarithmic models had similar $\mathrm{R}^{2}$ values but the Logarithmic model had higher $R M S E$ and $\chi^{2}$ values than former two models.

Figures 3 and 4 show the conformity of the best-fit models for time dependent changes in experimental $M R$ values at different temperatures for triangular and traditional Kayseri mantı samples, respectively.

Table 2. Conformance of experimental data for triangular mantı samples with theoretical models by nonlinear regression analysis.

\begin{tabular}{|c|c|c|c|c|c|c|c|}
\hline Model & Temperature $\left({ }^{\circ} \mathrm{C}\right)$ & \multicolumn{3}{|c|}{ Constant and Coefficients } & $\chi^{2}\left(\mathrm{x} 10^{-3}\right)$ & RMSE $\left(\mathrm{x} 10^{-2}\right)$ & $\mathrm{R}^{2}$ \\
\hline Henderson & 60 & $\mathrm{k}=0.0056$ & $a=1.0359$ & & 0.533 & 2.189 & 0.993 \\
\hline \multirow[t]{2}{*}{ and Pabis } & 70 & $\mathrm{k}=0.0060$ & $a=1.0492$ & & 0.317 & 1.683 & 0.995 \\
\hline & 80 & $\mathrm{k}=0.0060$ & $a=1.0116$ & & 0.149 & 1.155 & 0.996 \\
\hline \multirow[t]{3}{*}{ Newton } & 60 & $\mathrm{k}=0.0055$ & & & 0.020 & 0.423 & 0.993 \\
\hline & 70 & $\mathrm{k}=0.0058$ & & & 0.111 & 0.996 & 0.995 \\
\hline & 80 & $\mathrm{k}=0.0059$ & & & 0.155 & 1.179 & 0.996 \\
\hline \multirow[t]{3}{*}{ Page } & 60 & $\mathrm{k}=0.0089$ & $\mathrm{n}=0.9116$ & & 0.173 & 1.247 & 0.995 \\
\hline & 70 & $\mathrm{k}=0.0079$ & $\mathrm{n}=0.9436$ & & 0.151 & 1.162 & 0.996 \\
\hline & 80 & $\mathrm{k}=0.0096$ & $\mathrm{n}=0.9141$ & & 0.097 & 0.930 & 0.997 \\
\hline Modified & 60 & $\mathrm{k}=0.0056$ & $\mathrm{n}=0.9116$ & & 0.173 & 1.247 & 0.995 \\
\hline \multirow[t]{2}{*}{ Page } & 70 & $\mathrm{k}=0.0058$ & $\mathrm{n}=0.9436$ & & 0.151 & 1.162 & 0.996 \\
\hline & 80 & $\mathrm{k}=0.0062$ & $\mathrm{n}=0.9141$ & & 0.097 & 0.930 & 0.997 \\
\hline \multirow[t]{3}{*}{ Logarithmic } & 60 & $\mathrm{k}=0.0061$ & $a=1.0330$ & $c=0.0495$ & 11.324 & 1.132 & 0.992 \\
\hline & 70 & $\mathrm{k}=0.0070$ & $a=1.0402$ & $c=0.0468$ & 1.272 & 3.374 & 0.990 \\
\hline & 80 & $\mathrm{k}=0.0071$ & $a=1.0118$ & $c=0.0463$ & 1.003 & 3.001 & 0.993 \\
\hline
\end{tabular}

Table 3. Conformance of experimental results for traditional Kayseri mantı samples with theoretical models by nonlinear regression analysis.

\begin{tabular}{|c|c|c|c|c|c|c|c|}
\hline Model & Temperature $\left({ }^{\circ} \mathrm{C}\right)$ & \multicolumn{3}{|c|}{ Constant and Coefficients } & $\chi^{2}\left(\mathrm{x} 10^{-3}\right)$ & $R M S E\left(\mathrm{x} 10^{-2}\right)$ & $\mathrm{R}^{2}$ \\
\hline Henderson and & 60 & $\mathrm{k}=0.0054$ & $a=1.0624$ & & 21.593 & 13.975 & 0.991 \\
\hline \multirow{2}{*}{ Pabis } & 70 & $\mathrm{k}=0.0060$ & $\mathrm{a}=1.0142$ & & 0.272 & 1.558 & 0.995 \\
\hline & 80 & $\mathrm{k}=0.0057$ & $a=1.0663$ & & 22.266 & 14.231 & 0.985 \\
\hline \multirow[t]{3}{*}{ Newton } & 60 & $\mathrm{k}=0.0056$ & & & 0.020 & 1.835 & 4.073 \\
\hline & 70 & $\mathrm{k}=0.0060$ & & & 0.111 & 0.003 & 0.053 \\
\hline & 80 & $\mathrm{k}=0.0059$ & & & 0.155 & 2.089 & 4.359 \\
\hline \multirow[t]{3}{*}{ Page } & 60 & $\mathrm{k}=0.0126$ & $\mathrm{n}=0.8600$ & & 0.027 & 0.496 & 0.999 \\
\hline & 70 & $\mathrm{k}=0.0098$ & $\mathrm{n}=0.9100$ & & 0.117 & 1.027 & 0.997 \\
\hline & 80 & $\mathrm{k}=0.0171$ & $\mathrm{n}=0.8138$ & & 0.092 & 0.916 & 0.989 \\
\hline \multirow[t]{3}{*}{ Modified Page } & 60 & $\mathrm{k}=0.0061$ & $\mathrm{n}=0.8600$ & & 0.027 & 0.496 & 0.999 \\
\hline & 70 & $\mathrm{k}=0.0062$ & $\mathrm{n}=0.9100$ & & 0.117 & 1.027 & 0.997 \\
\hline & 80 & $\mathrm{k}=0.0067$ & $\mathrm{n}=0.8138$ & & 0.092 & 0.916 & 0.989 \\
\hline \multirow[t]{3}{*}{ Logarithmic } & 60 & $\mathrm{k}=0.0073$ & $a=1.0148$ & $c=0.0638$ & 5.604 & 0.991 & 0.992 \\
\hline & 70 & $\mathrm{k}=0.0071$ & $a=1.0147$ & $c=0.0457$ & 3.221 & 0.995 & 0.990 \\
\hline & 80 & $\mathrm{k}=0.0068$ & $a=1.0790$ & $c=0.0496$ & 16.687 & 0.985 & 0.993 \\
\hline
\end{tabular}



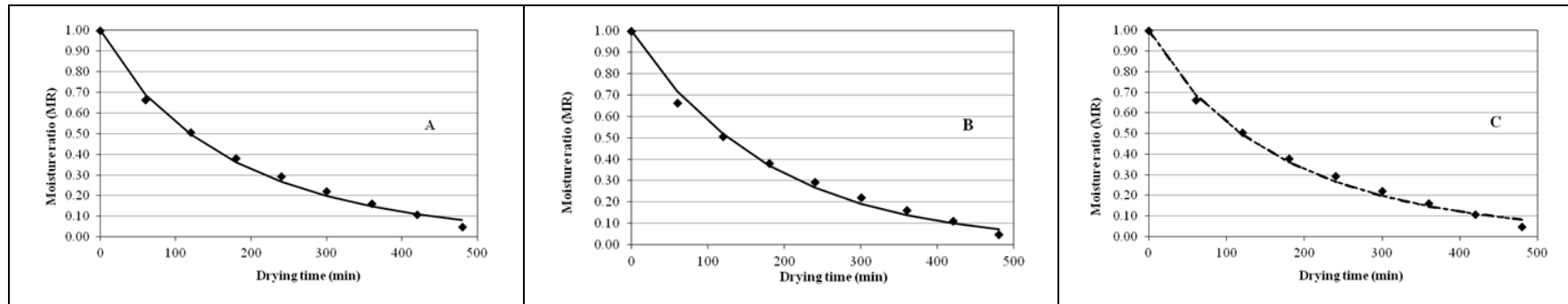

$\downarrow$ : Experimental $M R, \cdot-\cdot:$ Modified Page, - : Newton, and ---: Page models.

Figure 3. Time-dependent changes in the experimental and theoretical moisture ratio values for triangular mantı samples for the best-fit models. (a): Newton model at $60^{\circ} \mathrm{C}$, (b): Newton model at $70^{\circ} \mathrm{C}$, (c): Page and modified page models at $80^{\circ} \mathrm{C}$.

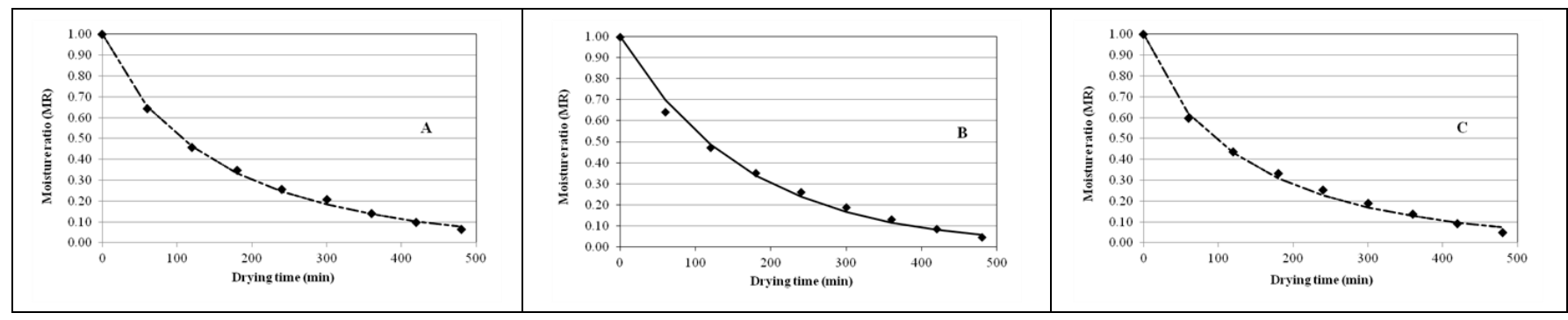

४: Experimental $M R, \cdot-\cdot:$ Modified Page, —: Newton, and ---: Page models).

Figure 4. Time-dependent changes in experimental and theoretical moisture ratio values for traditional Kayseri mantı samples for the best-fit models. (a): Page and Modified Page models at $60^{\circ} \mathrm{C}$. (b): Newton model at $70{ }^{\circ} \mathrm{C}$. (c): Page and Modified Page models at $80^{\circ} \mathrm{C}$

Pronyk [13] determined the drying characteristics of Asian noodles at three different superheated steam velocities and temperatures. Similar to the present study, Newton and Page models were the best models explaining the drying kinetics of noodles. The Modified Henderson equation was used to explain the drying data of pasta by Litchfield and Okos [26] and Japanese noodle by Inazu [14]. Investigating the drying properties of rice noodles in a hot air oven, Kongkiattisak and Songsermpong [24] reported that higher temperatures and air velocities decreased the moisture content of samples more efficiently while Two-Term and Logarithmic models were best semi-theoretical models explaining the drying characteristics of rice noodles.

Kaushal and Sharma [27] investigated the drying characteristics of noodles prepared with different flours and dried in a convective dryer for four different temperature levels. Rehydration reduced with an increase in drying temperature, and Verma model was the most suitable model for the compliance of experimental $M R$ data. Studying the drying characteristics of sorghum crackers dried in a tray dryer, Susanti et al. [28] reported that Newton and Lewis models properly fit to estimate the moisture content of the samples at different air velocities.

Zhou et al. [29] conducted the drying process of instant noodles with convective air dryer at five different temperature and three different air velocities, and drying process occurred in a falling rate period, which was the best described with the logarithmic model. In a study of the thin layer baking-drying kinetics for crisp breads, Page, Wang \& Singh and logarithmic models were observed to the best explain the baking-drying process [25].

Lertworasirikul [23] determined the drying kinetics of cassava crackers in a hot air drier for different temperature levels. Among the empirical models, Modified Page model was determined as the most suitable to explain drying process. Chen et al. [30] modelled the rehydration process of dumpling wrapper for three different temperatures in a freeze-drier. Rehydration characteristics of dumpling wrapper were directly influenced by drying temperature, and Peleg and Weibull models were well-fitted with rehydration process of dumpling wrapper. Results indicated that the water activity values of the triangular mantı samples reduced below to the desired value of 0.6 faster than those of the traditional Kayseri mantı samples due to the higher drying rates obtained in the former ones. Also, drying time and rate declined substantially with an increase in drying temperature. The Page, Modified Page and Newton models were the most suitable models at different temperature levels. Results indicated that triangle mantı samples should be dried at temperatures higher than $70{ }^{\circ} \mathrm{C}$ while temperatures higher than $80{ }^{\circ} \mathrm{C}$ are highly recommended for drying traditional Kayseri mantı samples.

\section{Conclusions}

In the current study, the drying kinetics of different types of mantı (Turkish ravioli) samples, which is one of the most consumed traditional foods of Turkish cuisine, were determined. Water activity values of the triangular mantı samples reduced below to the desired value of 0.6 faster than those of the traditional Kayseri mantı samples because of the higher drying rates obtained in the former ones. Moreover, the water activity of traditional Kayseri mantı samples fell below the desired value only after $8 \mathrm{~h}$ of drying at $80^{\circ} \mathrm{C}$. Drying time and rate declined substantially with an increase in drying temperature. Only a falling rate period was observed for two types of mantı samples. The Page, Modified Page and Newton models were the most suitable models at different temperature levels. Results indicated that triangle mantı samples should be dried at temperatures higher than $70{ }^{\circ} \mathrm{C}$ while temperatures 
higher than $80^{\circ} \mathrm{C}$ are highly recommended for drying traditional Kayseri mantı samples.

\section{Nomenclature}

$\mathrm{a}_{\mathrm{w}} \quad$ : Water activity,

DM : Dry matter content of mantı (g),

$m \quad$ : Sample weight $(\mathrm{g})$,

$M_{0} \quad$ : Initial moisture content (g water $\mathrm{g}^{-1}$ dry matter),

MC : Moisture content,

$M_{e} \quad$ : Equilibrium moisture content (g water $\mathrm{g}^{-1}$ dry matter),

$M R \quad$ : Moisture ratio,

$M R_{\text {exp }} \quad$ : Experimental moisture content,

$M R_{\text {prd }}$ : Estimated moisture content,

$M_{t} \quad$ : Moisture content at any $\mathrm{t}$ time (g water $\mathrm{g}^{-1}$ dry matter),

$\mathrm{M}_{\mathrm{t}+\mathrm{dt}} \quad$ : Moisture content at $\mathrm{t}+\mathrm{dt}$ time ( $\mathrm{g}$ water $\mathrm{g}^{-1}$ dry matter),

$n \quad$ : Number of coefficients in the tested model,

$N \quad$ : Number of the experimental data,

$\mathrm{R}^{2} \quad$ : Coefficient of determination

RMSE : Root mean square error,

$\chi^{2} \quad$ : Chi-square.

\section{References}

[1] Sanlier N. "Opinions of foreign and Turkish tourists on Turkish cuisine". Gazi University Journal of Gazi Educational Faculty, 25(1), 213-227, 2005.

[2] Daglioglu O. Microwave Drying of Turkish Ravioli and the Effects of Microwave Drying on the Final Product. PhD Thesis, Trakya University, Tekirdağ, Turkey, 1993.

[3] Budak N, Sahin H, Cicek B. Kayseri Mantıları, Türk Mutfak Kültürü Üzerine Araştırmalar. Ankara, Türkiye, Türk Halk Kültürünü Araștırma ve Tanıtma Vakfı Yayınları, 2002.

[4] Farber JM, Dodds K. Principles of Modified-Atmosphere and Sous Vide Product Packaging. $1^{\text {st }}$ ed. Pennsylvania, USA, CRC Press, 1995.

[5] Rodriguez V, Medina LM, Jordano R. "Incidence of mesophilic anaerobic bacteria and lactic acid bacteria on sliced bread under modified atmosphere packaging during storage". Journal of Food Quality, 22(6), 701-710, 1999.

[6] Ünlütürk A, Turantaş F. Gıda Mikrobiyolojisi. Birinci baskı. Izmir, Turkey, Mengi tan Basımevi, 1999.

[7] Ramos IN, Silva CLM, Sereno AM, Aguilera JM. "Quantification of microstructural changes during first stage air drying of grape tissue". Journal of Food Engineering, 62, 159-164, 2004.

[8] Zhang M, Tang J, Mujumdar AS, Wang S. "Trends in microwave related drying of fruits and vegetables". Trends in Food Science \& Technology, 17, 524-534, 2006.

[9] Ozgener L, Ozgener 0. "Exergy analysis of industrial pasta drying process". International Journal of Energy Research 30(15), 1323-1335, 2006.

[10] De pilli T, Giuliani R, Derossi A, Severini C. "Effects of microwave drying on lipid oxidation of stuffed pasta". Journal of American Oil Chemists' Society, 85, 827-834, 2008.
[11] Mercier S, Villeneuve S, Mondor M, Des marchais LP. "Evolution of porosity, shrinkage and density of pasta fortified with pea protein concentrate during drying". LWT-Food Science and Technology, 44(4), 883-890, 2011.

[12] Colak N, Erbay Z, Hepbasli A. "Performance assessment and optimization of industrial pasta drying". International Journal of Energy Research, 37(8), 913-922, 2013.

[13] Pronyk CW. Effects of Superheated Steam Processing on the Drying Kinetics and Textural Properties of İnstant Asian Noodles. PhD Thesis, The University of Manitoba, Winnipeg, Canada, 2007.

[14] Inazu T, Iwasaki KI, Furuta T. "Desorption isotherms for Japanese noodle (udon)”. Drying Technology, 19(7), 1375-1384, 2001.

[15] Mamat KA, Yusof MS, Yusoff WFW, Rahim MZ, Hassan S, Rahman MQA, Karim MA. "Dehydration of traditional dried instant noodle (mee siput) using controlled temperature \& humidity dryer". IOP Conference Series: Materials Science and Engineering, Johor Bahru, Malaysia, 19-20 April 2017.

[16] Darvishi H, Azadbakht M, Rezaeiasl A, Farhang A. "Drying characteristics of sardine fish dried with microwave heating". Journal of the Saudi Society of Agricultural Sciences, 12(2), 121-127, 2013.

[17] Maskan M. "Drying, shrinkage and rehydration characteristics of kiwifruits during hot air and microwave drying". Journal of Food Engineering, 48(2), 177-182, 2001.

[18] Henderson SM, Pabis S. "Grain drying theory I: Temperature effect on drying coefficient". Journal of Agricultural Engineering Research, 6, 169-174, 1961.

[19] Lewis WK. "The rate of drying of solid materials". Industrial \& Engineering Chemistry, 13(5), 427-432, 1921.

[20] Page GE. Factors Influencing the Maximum Rate of Air Drying Shelled Corn in Thin-Layers. MSc Thesis, Purdue University, West Lafayette, USA, 1949.

[21] White GM, Bridges TC, Loewer OJ, Ross IJ. "Seed coat damage in thin layer drying of soybeans as affected by drying conditions". Transactions of the ASAE, 23(1), 224-227, 1978.

[22] Chandra PK, Singh RP. Applied Numerical Methods for Food and Agricultural Engineers, CRC Press, Boca Raton, USA, 1995.

[23] Lertworasirikul S. "Drying kinetics of semi-finished cassava crackers: A comparative study". LWT-Food Science and Technology, 41(8), 1360-1371, 2008.

[24] Kongkiattisak P, Songsermpong S. "Effect of temperature and velocity of drying air on kinetics, quality and energy consumption in drying process of rice noodles". Kasetsart Journal-Natural Science, 46, 603-619, 2012.

[25] Salari A, Tehrani MM, Razavi SM. "Baking-drying kinetics of crisp bread: The influence of bran content and baking temperature". Iranian Food Science and Technology Research Journal, 11(3), 225, 2015.

[26] Litchfield JB, Okos MR. "Moisture diffusivity in pasta during drying". Journal of Food Engineering, 17(2), 117-142, 1992.

[27] Kaushal P, Sharma HK. "Convective dehydration kinetics of noodles prepared from taro (Colocasia esculenta), rice (Oryza sativa) and pigeonpea (Cajanus cajan) flours". Agricultural Engineering International: CIGR Journal, 15(4), 202-212, 2013. 
[28] Susanti DY, Karyadi JNW, Mariyam S. "Drying characteristics of crackers from sorghum using tray dryer in different drying air velocities". Journal of Advanced Agricultural Technologies, 3(4), 258-263, 2016.

[29] Zhou M, Xiong Z, Cai J, Xiong H. "Convective air drying characteristics and qualities of non-fried instant noodles". International Journal of Food Engineering, 11(6), 851-860, 2015.
[30] Chen W, Li H, Jiao X, Gui X. "Study on freeze-drying process of dumpling wrappers". Advance Journal of Food Science and Technology, 8(6), 440-445, 2015. 